\title{
enorden
}

\section{Gæði og mikilvægi menntunar og rannsókna}

Samstarfsáætlun Norrænu rádherranefndarinnar um menntamál og rannsóknir (MR-U) frá og med árinu 2015

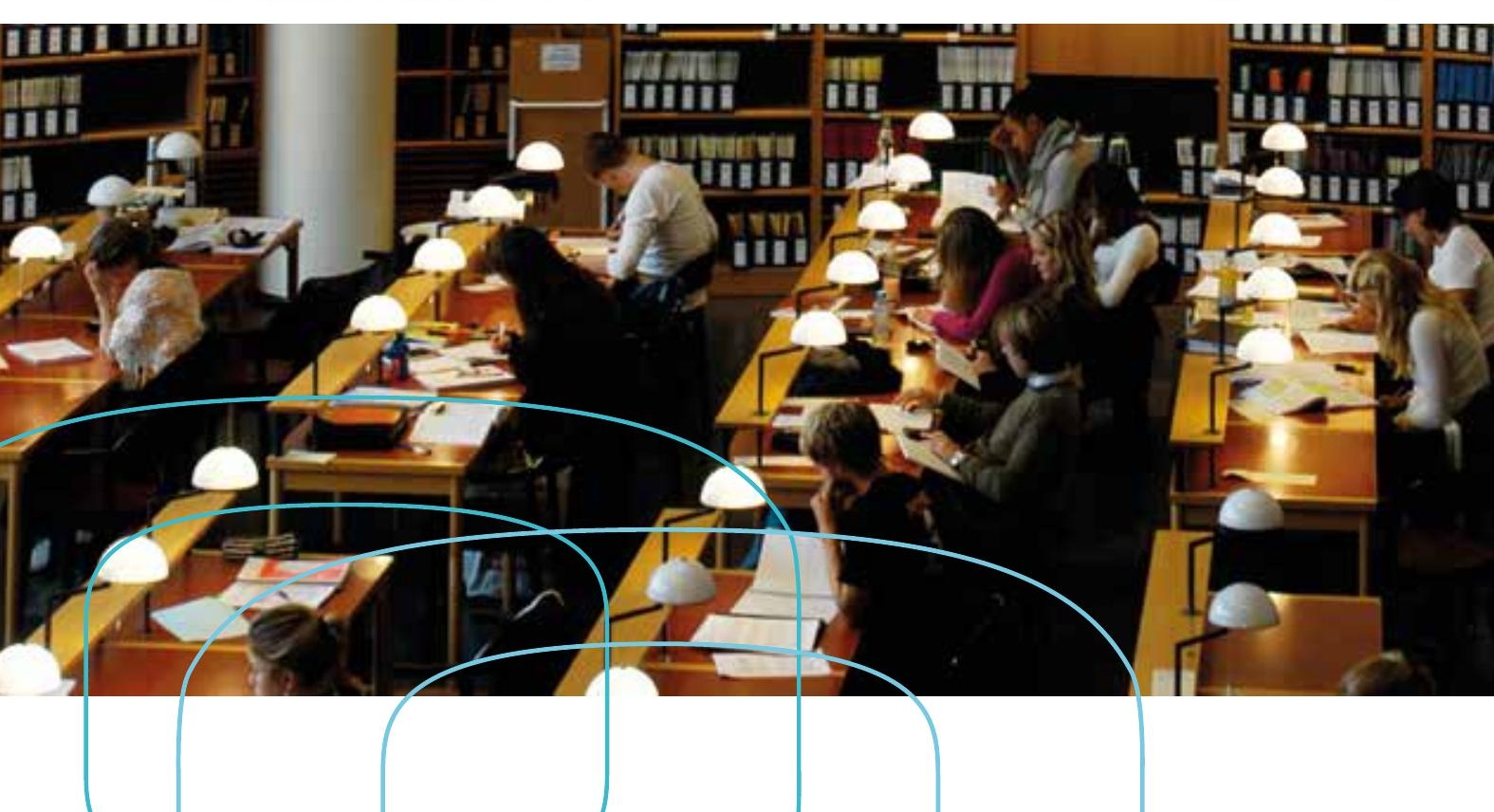


Gæði og mikilvægi menntunar og rannsókna

Samstarfsáætlun Norrænu ráðherranefndarinnar um menntamál og rannsóknir (MR-U) frá og med árinu 2015

ISBN 978-92-893-4207-0 (PRINT)

ISBN 978-92-893-4208-7 (PDF)

http://dx.doi.org/10.6027/ANP2015-758

ANP 2015:758

(c) Norræna ráðherranefndin 2015

Umbrot: Gitte Wejnold

Kápumynd: Norden.org

Ljósmyndir: Norden.org, Signelements.com

Prentun: Rosendahls-Schultz Grafisk

Upplag: 100

Leturgerd: Meta LF

Pappír: Munken Polar

Printed in Denmark

www.norden.org/nordpub

\section{Norrænt samstarf}

Norræna samstarfið er eitt umfangsmesta svæðasamstarf í heiminum. Samstarfið nær til Danmerkur, Finnlands, Íslands, Noregs og Svípjódar auk Álandseyja, Færeyja og Grænlands.

Norræna samstarfið er pólitískt, efnahagslegt og menningarlegt og skiptir miklu í evrópsku og alpjódlegu samstarfi. Í norrænu samstarfi er unnið að pví að styrkja stöðu Norðurlanda í sterkri Evrópu.

Með norrænu samstarfi er unnið að pví að efla norræna og svæðisbundna hagsmuni i alpjóðlegu umhverfi. Sameiginleg gildi landanna styrkja stöðu Norðurlanda og skipa peim medal peirra svæða í heiminum par sem nýsköpun og samkeppnishæfni er mest.

\section{Norræna rádherranefndin}

Ved Stranden 18

DK-1061 København K

Sími (+45) 33960200 


\section{Gæði og mikilvægi menntunar og rannsókna}

Samstarfsáætlun Norrænu rádherranefndarinnar um menntamál og rannsóknir (MR-U) frá og medárinu 2015 


\section{Formáli}

Samstarf Norðurlandanna hefur löngum byggst á trausti og sameiginlegum

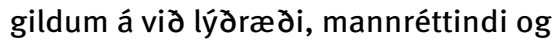
sjálfbærni. Norræna rádherranefndin hefur í áranna rás verid formlegur samstarfsvettvangur sem stjórnvöld hafa nýtt til ad skapa samlegðaráhrif og skiptast á lausnum á ýmsum svidum í págu almennings á Nordurlöndum. Nú er hafið umfangsmikið nútímavæðingarferli hjá Norrænu rádherranefndinni í pví skyni ad hleypa nýju lífi í samstarfid

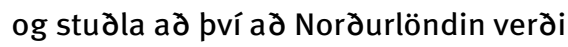
sýnilegur og opinn vettvangur nýsköpunar og án stjórnsýsluhindrana. Petta er gert á sama tíma og velferdarsamfélög Norðurlanda standa frammi fyrir vidfangsefnum sem markast af heimsvæðingu og efnahagskreppu, breyttri aldurssamsetningu almennings ásamt stödu loftslags- og orkumála.

Framtídarsýn norræns samstarfs um menntamál og rannsóknir byggist á

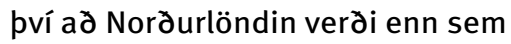
fyrr forystusvæði á sviði pekkingar og velferðar. Markmið samstarfsins er ad skapa vel starfandi mennta- og rannsóknasamfélag á Norðurlöndum. Pær pjódir sem byggja Nordurlöndin eru nánar, landfrædilega, sögulega og menningarlega. Menntakerfi landanna eru um margt lík og viðfangsefnin hin sömu. Samstarf landanna skilar betri árangri en ef löndin standa ein - stofnunum jafnt og almenningi til gagns og gledi.

Samstarfsáætlun Norrænu rádherranefndarinnar um menntamál og rannsóknir (MR-U) markar stefnu í rádherrasamstarfi á svidum menntamála, rannsókna, tungumála og upplýsingatækni frá og med árinu 2015. Takmarkid med áætluninni er ad brýna áherslur og markmið samstarfsins en pad rædst af peim pólitísku áherslum sem eru ofarlega á baugi í löndunum sem og á Álandseyjum, í Færeyjum og á Grænlandi. Íáætluninni er lýst peim meginprádum sem rádherrarnir vilja beina sjónum ad og inniheldur hún pví ekki tæmandi yfirlit yfir öll forgangsmál rádherranefndarinnar (MR-U). Rádherranefndin mun ræda og endurskoda samstarfsáætlunina reglulega med hliðsjón af nýjum pólitískum áherslum. Á pann hátt er stefnt à pví ad styðja áframhaldandi próun á samstarfi og samstarfsleiðum rádherranefndarinnar á sviði menntamála og rannsókna. Áætluninni fylgir listi yfir

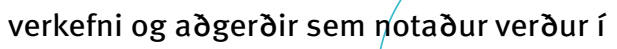
innra starfi rádherranefndarinnar (MR-U). 


\section{Helstu pættir á svidi menntamála}

Norrænt samstarf um menntamál nær til leikskóla, grunnskóla, framhaldsskóla,

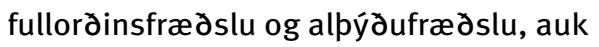
æəri menntunar.

Í norrænu samstarfi um menntun aldurshópsins 0-18 ára og fullorðinsfrædslu er áhersla lögd á ad auka gædi í leikskólum, kennslu og menntun. Markmiðid er ad próa menntun í gódu námsumhverfi sem studlar ad pví ad öll börn og ungmenni, drengir og stúlkur, geti próad andlega og líkamlega færni

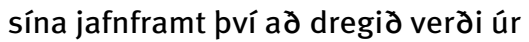
áhrifum félagslegrar stödu peirra og ad öll fái pau tækifæri til ad læra og proskast alla ævi. Helstu pættir sem unnið verður að:

1. auka grunnfærni og pekkingu barna, ungmenna og fullordinna, drengja og stúlkna / kvenna og karla med pví ad

- efla samstarf um pekkingu og greiningu á mikilvægum viðfangsefnum á sviði menntunar fyrir aldurshópinn 0-18 ára og

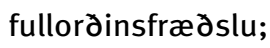

- studla ad próun menntunar á Norðurlöndum med aukinni áherslu á stjórnun, forystu og umbætur;

- stydja vid próun á og notkun nýrra kennslu- og námsadferða, til dæmis med aukinni áherslu á frumkvöəlastarf, hugvit og nýsköpun ásamt flutningi gagna á stafrænt form;

2. auðvelda umskipti milli menntastiga og milli skóla og vinnumarkaðar;

3. auka námstækifæri ungmenna og fullorðinna, meðal annars med pví að hvetja fleiri ungmenni til ad ljúka starfsnámi;

4. auka virðingu fyrir starfsmenntun og bæta námsumhverfi á vinnustödum fyrir ungmenni og fullorðna.

Samstarf á sviði æðri menntunar tekur mið af aukinni alpjódasamkeppni par sem brýnt er að greina styrkleikasvið og auka hreyfanleika innan pekkingargeirans. Helstu pættir sem unnið verður à: 
5. hvetja til aukins samstarfs um skipulag og uppbyggingu æðri menntastofnana á Norðurlöndum, til ad mynda á pröngum fræðasviðum og próa norrænu meistaranámsáætlunina enn frekar;

6. vekja athygli á æðri menntun med pví

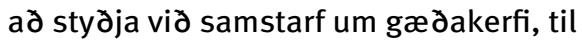
dæmis par sem löndin skiptast á reynslu af próun gæðamatskerfa á tilteknum sviðum.

Tveir pættir eiga við um allt námsferlið:

7. Eflt samstarf um kennaramenntun, kennarastarfid sem og endur- og framhaldsmenntun kennara, pannig à samstarfið spanni allt ferli kennaramenntunar.

8. Aukin samkeppnishæfni norrænna menntastofnana á alpjódamarkaði, til dæmis med pví ad kanna forsendur fyrir kynningu á menntun á Norðurlöndum á alpjódavettvangi og eftirspurn eftir henni.

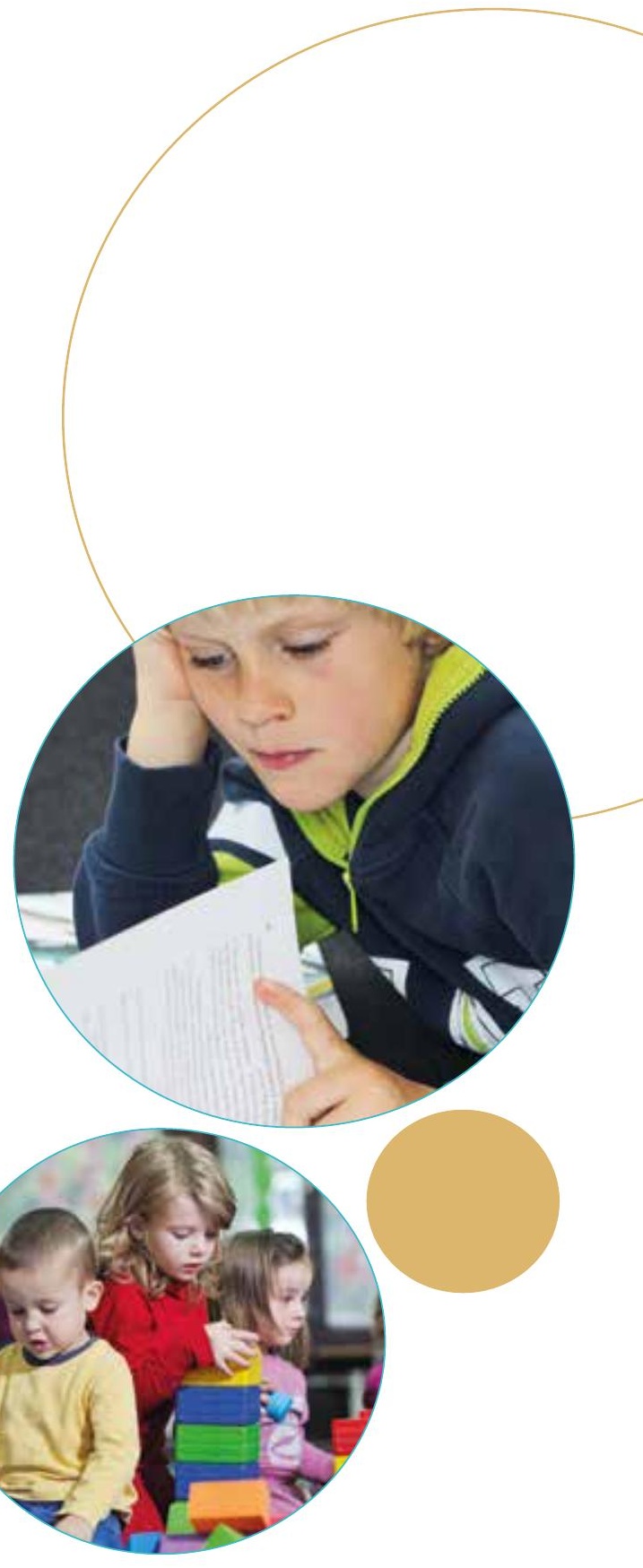




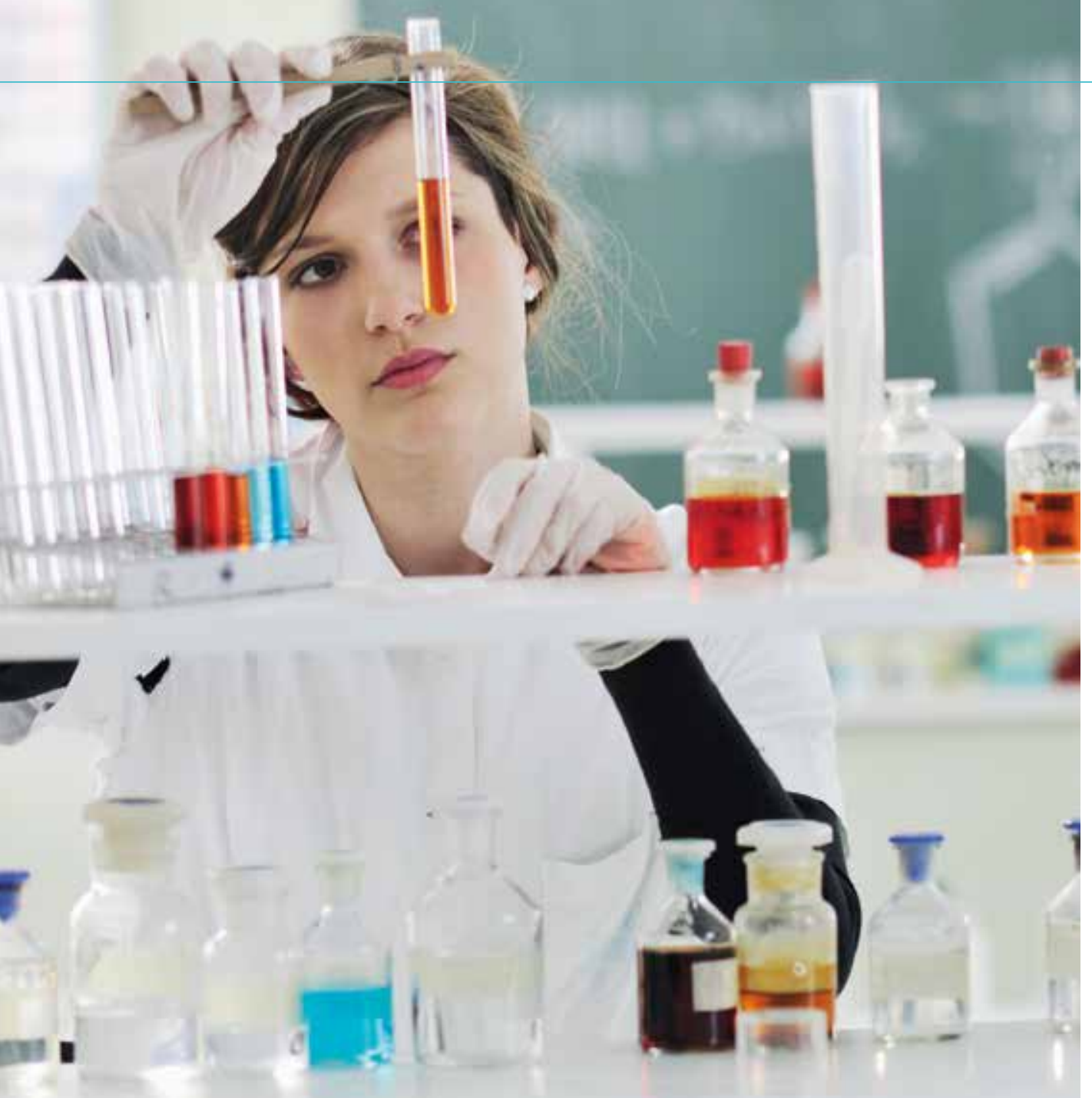




\section{Helstu pættir á sviði rannsókna}

Pekking byggdá vísindalegum grunni er mikilvæg forsenda pess að hægt sé að skapa hagvöxt og takast á við ýmis samfélagsleg vidfangsefni. Próad norrænt samstarf um rannsóknir eykur gædi og áhrif peirra. Samstarfid skapar einnig virdisauka fyrir rannsóknarstofnanir og löndin vegna pess að sparnaður næst í útgjöldum og líkur aukast á pví ad hljóta rannsóknastyrki úr áætlunum og verkefnum Evrópusambandsins.

\section{Rádherranefndin (MR-U) vill studla ad}

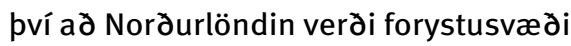
í heiminum á sviði pekkingar med eftirtalda pætti að leidarljósi:

1. að styðja við pverfaglegt rannsókna-
2. ad efla samstarf um rannsóknir á hugsanlegum öndvegisrannsóknasviðum, par á medal mikilvægum stefnumótandi svidum par sem pörf er á sameiginlegum

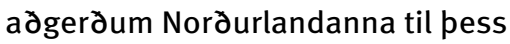
à byggja upp og styrkja færni á sviði rannsókna og menntunar sem er á heimsmælikvarða;

3. ad efla samstarf um og samnýtingu á innviðum rannsókna á Norðurlöndum.

Hápróad norrænt rannsóknasamstarf getur ennfremur skapad nýja pekkingu á forgangssviðum rádherranefndarinnar (MR-U), til dæmis hvað vardar menntamál, norræn tungumál og tungumálasamskipti.

samstarf milli stofnana í löndunum og norrænna stofnana sem fjármagna rannsóknir; 


\section{Helstu pættir í tungumálasamstarfi}

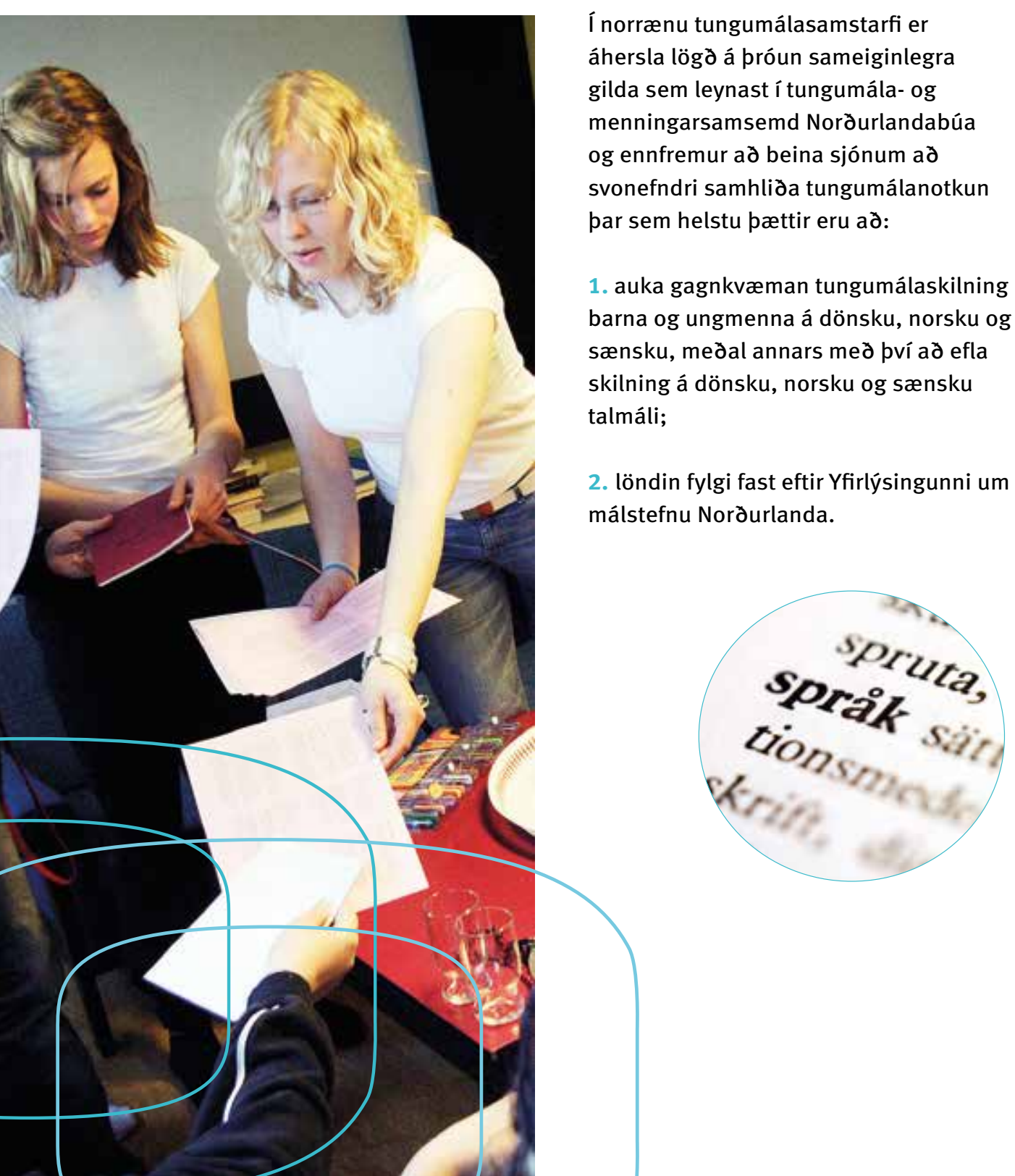

Í norrænu tungumálasamstarfi er âhersla lögdá próun sameiginlegra gilda sem leynast í tungumála- og menningarsamsemd Norðurlandabúa og ennfremur ad beina sjónum ad svonefndri samhlida tungumálanotkun par sem helstu pættir eru ad:

1. auka gagnkvæman tungumálaskilning barna og ungmenna á dönsku, norsku og sænsku, meðal annars með pví ad efla skilning á dönsku, norsku og sænsku talmáli;

2. löndin fylgi fast eftir Yfirlýsingunni um málstefnu Norðurlanda. 


\section{Helstu pættir í samstarfi um upplýsingatækni}

Norrænt samstarf á sviði upplýsingatækni miðar að pví að auðvelda einstaklingum og fyrirtækjum á Norðurlöndum að færa sig á milli landa og ennfremur ad auka gædi stafrænnar pjónustu opinberra yfirvalda á Norðurlöndum.

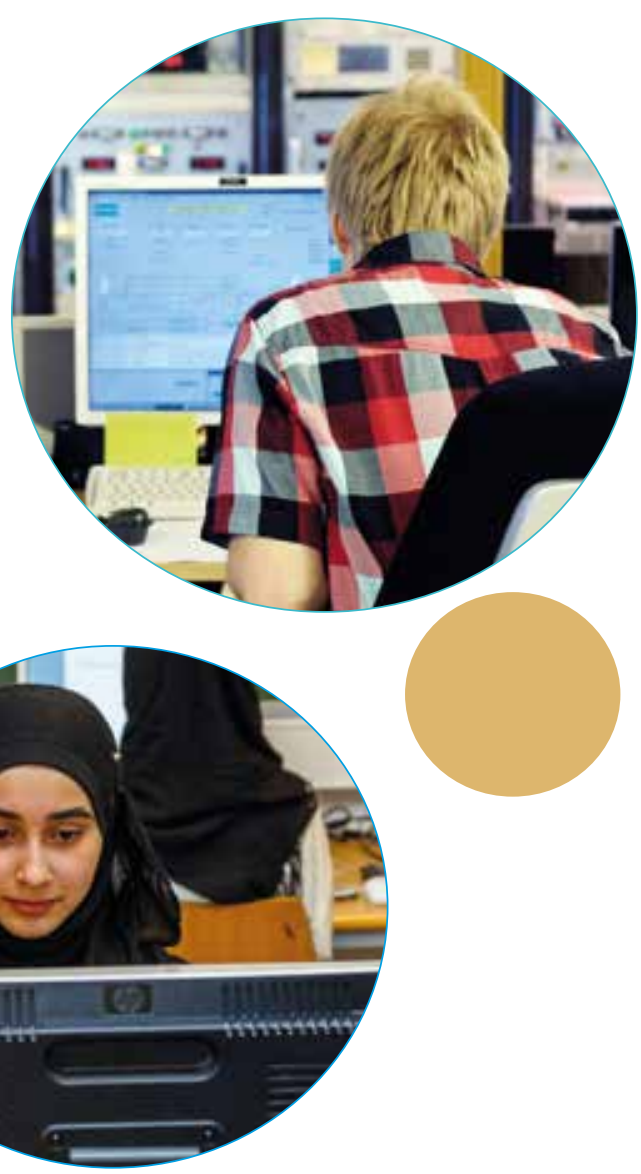




\section{Samstarfsleiðir}

Rádherranefndin (MR-U) hefur löngum átt öflugt og uppbyggilegt samstarf um viðfangsefni og aðgerðir sem pjóna sameiginlegum hagsmunum landanna á svidi menntamála og rannsókna. Peir pættir sem rádherranefndin (MR-U) mun eiga samstarf um til lengri tíma litið eru:

Menntunar-og tengslanetaáætlanir:

- Nordplus,

- Norræna meistaranámsáætlunin (NMP),

- Norræna tengslanetið um

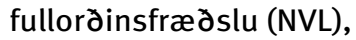

- Samhæfing á norrænu tungumálasamstarfi (NOSK).

\section{NordForsk}

\section{Samstarfsstofnanirnar fimm:}

- Norræna kjarneðlisfræðistofnunin (NORDITA),

- Norræna sjóréttarstofnunin (NIfS),

- Norræna stofnunin um Asíurannsóknir (NIAS),

- Norræna eldfjallasetrið (NORDVULK)

- Norræna Samastofnunin (NSI),
Tímabundnir vinnuhópar og verkefni

Norrænn vettvangur fyrir midlun reynslu og pekkingar, menntun og gagnkvæma hvatningu.

Norrænir samningar:

- Samningur milli Íslands, Danmerkur, Finnlands, Noregs og Svípjódar um rétt norrænna ríkisborgara til à nota eigin tungu í ödru norrænu landi (Tungumálasáttmálinn),

- Yfirlýsing um málstefnu Norðurlanda (Tungumálayfirlýsingin),

- Samningur milli Danmerkur, Finnlands, Íslands, Noregs og

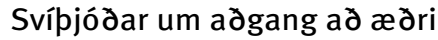
menntun,

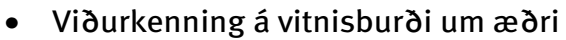
menntun - „Reykjavíkuryfirlýsingin“,

- Samningur milli Danmerkur, Finnlands, Íslands, Noregs og Svípjódar um norrænt menntunarsamfélag á framhaldsskólastigi.

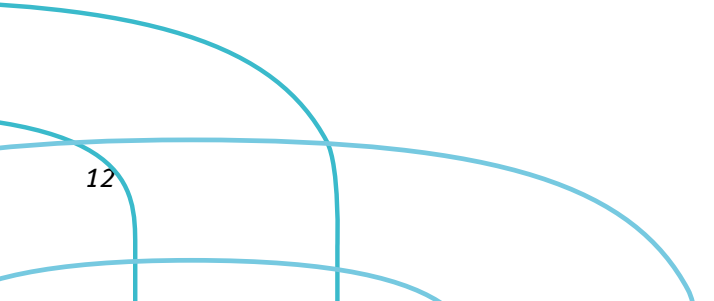


Rannsóknir, greiningar, úttektir, mat o.p.h.

\section{Samstarfog samrád við norræn} samtök og stofnanir á verksviði rádherranefndarinnar (MR-U)

Mörg verkefni verða best leyst í samstarfi ýmissa fagrádherranefnda, en rádherranefndin (MR-U) á samstarf við aðrar rádherranefndir um nánari útfærslu á pverfaglegum viðfangsefnum, áætlunum og stefnumótunum. Samstarfið á meðal annars við um eftirfarandi áætlanir:

- Sjálfbæra norræna velferd (HVN)

- Menntun og rannsóknir á svidi græns hagvaxtar

- Norræna samstarfsáætlun um jafnréttismál 2015-2018

- Framkvæmdaáætlun fyrir norrænt samstarf um málefni fatlaðra 2015-2017

- Stefnu í málefnum barna og ungmenna á Norðurlöndum

- Norræna áætlun um sjálfbæra próun

- Stefnumótun og framkvæmdaáætlun um frjálsa för innan Norðurlandanna 2014-2017 (samstarf um afnám stjórnsýsluhindrana).
Rádherranefndin (MR-U) á samstarf vid ýmsar svæðisbundnar og alpjódlegar stofnanir um verkefni og sóknarfæri sem pjóna sameiginlegum hagsmunum adila. 

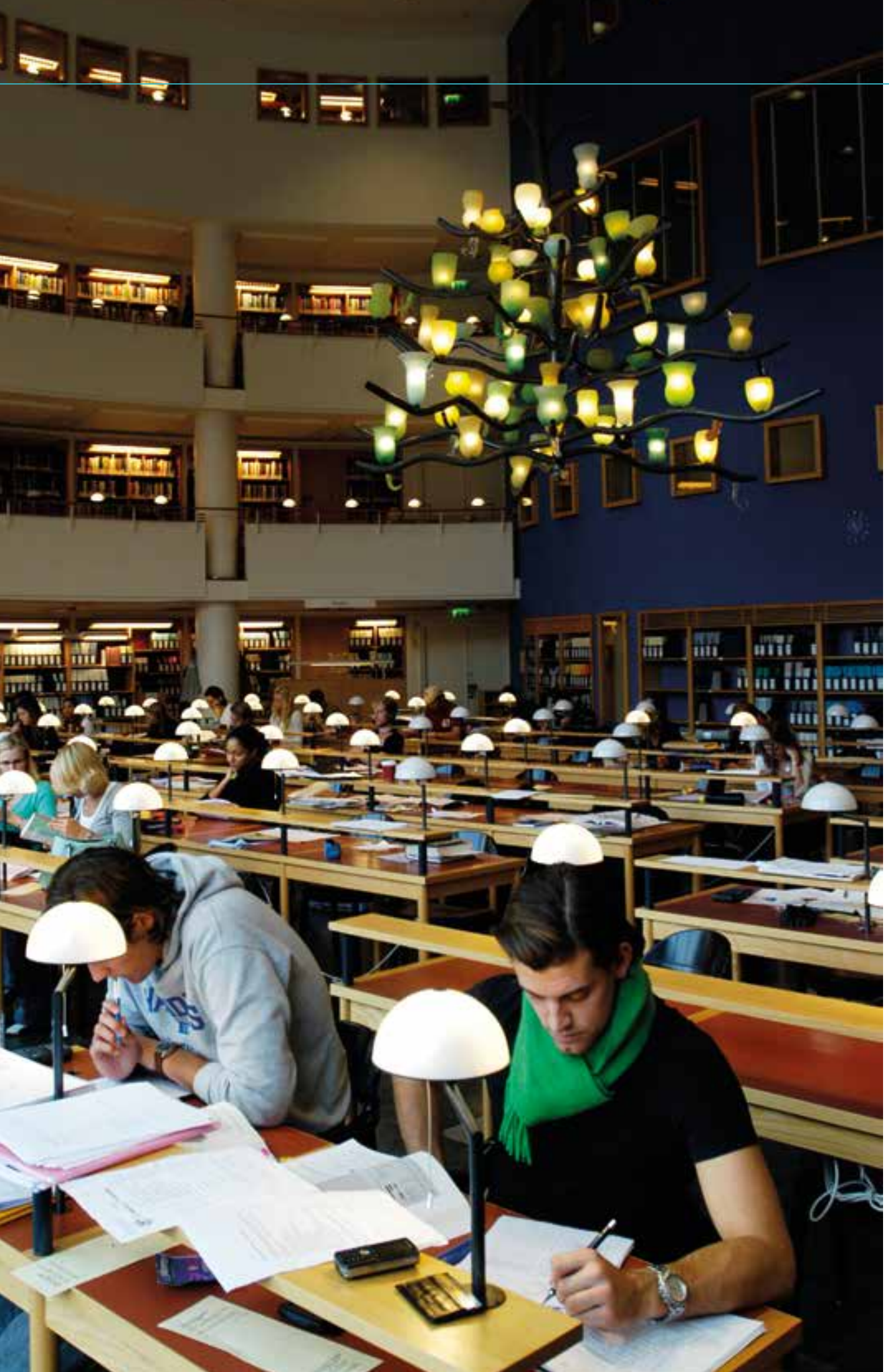


\section{Lokaord}

Markhópur áætlunarinnar er rádherranefndin (MR-U) og allir sem starfa á hennar vegum við að hrinda markmiðum norræns samstarfs á sviði menntamála og rannsókna í framkvæmd.

Norræna ráðherranefndin leggur áherslu á ad áætlunin gagnist öllum sem málid varðar sem leidarljós i samstarfinu í framtídinni. 


\section{norden}

Norræna rádherranefndin

Ved Stranden 18

DK-1061 København K

www.norden.org

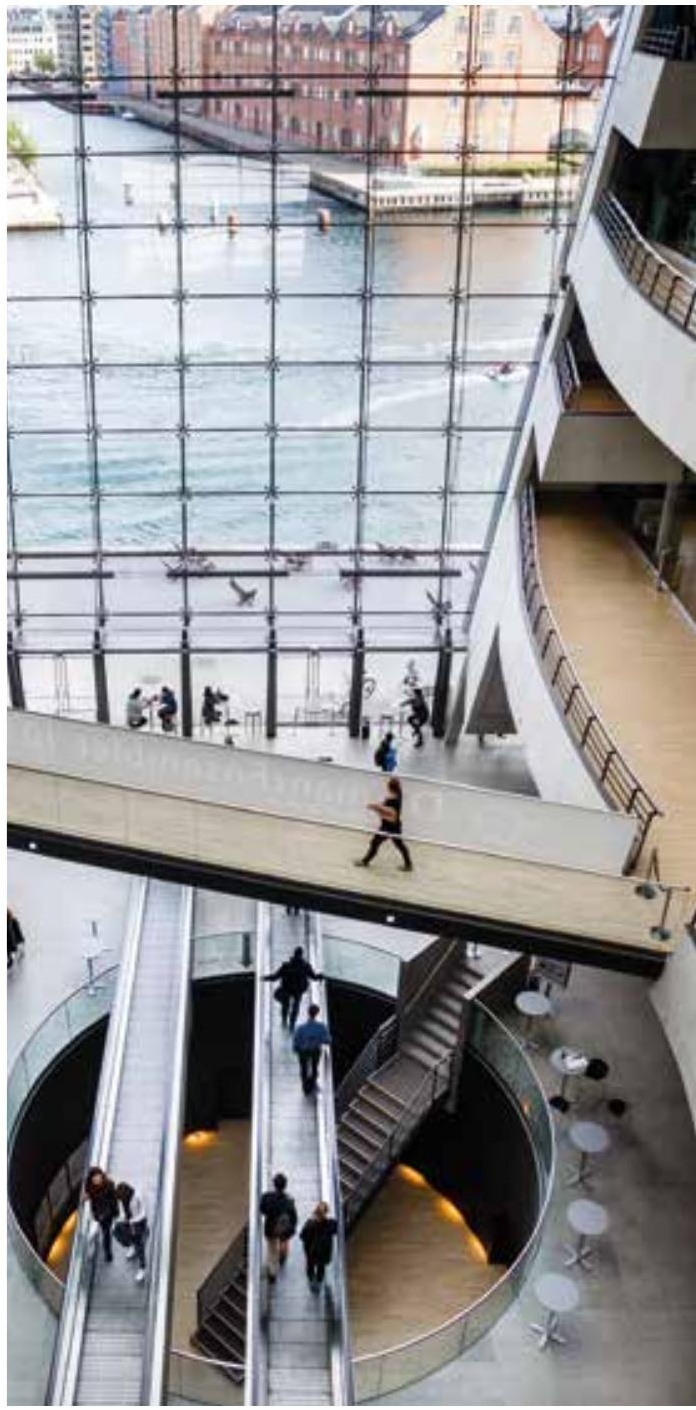

